\title{
Critical Analysis of Identity Crisis in Hanif Kurieshi's Novel "The Buddha of Suburbia"
}

\author{
* Muhammad Azeem, PhD Scholar (Corresponding Author) \\ ** Prof. Dr. M K Sangi, Professor \\ *** Dr. Komal Ansari
}

\begin{abstract}
This paper critically analyzes the dilemma of identity crisis and its impact on immigrants concerning the Hanif Kurieggidentity crisis into its texts because of the rule of colonial power and its impacts on the colonized. Under the impact of this colonial power, the crisis of identity has been originated in western countries on social, economic, political, religious, and cultural grounds. Postcolonial theoretical ideas i.e, hybridity, mimicry, assimilation, and ambivalence by Homi K. Bhabha are applied into the text of this research paper to examine the dilemma of identity crisis more clearly. Karim Amir, the protagonist of the novel faces an identity crisis in tormenting and perturbing the social order of England. Such a tormenting and disturbing condition of England is a threat both to Karim and immigrants. The quest for an identity for Karim Amir is very complicated and alarming which sets a dilemma for the whole world to look at this global issue seriously. The Whites think about immigrants as they are the lower creature of God due to differences in skin color, religion, ethnicity, and culture. On the contrary, the immigrant trying to imitate the cultural values, language, habits, and manners of the white men to assimilate with them but in consequence, this mimicry never fetched the desired effects and simply, the outcome is ambivalent for them. Although they always try to assimilate with the British culture, yet they feel hesitant either to adopt Western culture or the culture of their homeland. The Buddha of Suburbia (1989) depicts the darker side of suburban life as well as the congested life of London city with references to other characters too.
\end{abstract}

Keywords: Crisis of Identity, Perturbing, Ambivalent, Post-colonialism, Quest for Identity. Introduction Postcolonial Study

Identity crisis is a major dilemma all over the world especially with the countries that were then the colonies of the British Empire. The British Empire ruled over them for many years and thus transmitted its culture and traditions into the colonized countries which result in multiculturalism. Being an author of postcolonial English fiction, Hanif Kureishi has a Pakistani descent. His works deal mostly with race issues, hybrid culture, color binaries, clash with religion and ethnicity. His first award-winning novel "The Buddha of Suburbia (1989)" depicts these issues through which the protagonist Karim Amir and other characters face. They are always busy searching for their true identity in English soil and discover who they are? The protagonist Karim Amir worries about his present status in a foreign land. He remains concerned for his identity as he never assimilates with the western culture wholly. Being engaged with two opposite cultures, Kureishi's protagonist struggles to maintain his individuality. Karim Amir cannot neglect his root and Indian identity. Based on culture, he seems to be adjusted with one category but at the very next moment, he remains in a circle of many races and cultures. Karim's recognition in England is through religion, culture, gender, and class. According to Kaleta (1998 p.6), the work of Hanif Kureishi throws light on those characters who are interested in the traditions of their past, especially with their Asian life. She argues that such an interest in a past life is an indication of their ignorance and misperception. About hybrid culture especially with related to sexuality and masculinity, Hanif Kureishi's fiction highlight the subjects i.e, individuality, and ambivalence.

* Institute of English Language \& Literature University of Sindh, Jamshoro.

Email: cdglmuhammadazeem@gmail.com

** Institute of English Language \& Literature University of Sindh, Jamshoro. Email: sangi_mk@ yahoo.com

*** Institute of English Language and Litertaure University of Sindh, Jamshoro.

Email: komal.ansari@gmail.com 
According to a famous critic Kara, (2020), through the character of Karim Amir, the author of the novel portrays Western's biased attitudes towards Pakistani immigrants. These are called the firstgeneration immigrants as well as the immigrants of the second generation. Youth like Karim Amir and Jamila represent the first generation immigrants while Haroon and Anwar are the depictions of second-generation immigrants. He observed that in the $20^{\text {th }}$ century, the migration policy of the UK was very rigid which has created a sense of absurdity among immigrants. During the 20th century, the British's one-sided racist policy which excluded the diasporic from the world started to change and the British society transformed into a culturally mixed one by dealing with the people from different parts of the world. At that time language was a means of power that shaped identity.

In this era, England experienced a lot of economic recession, growing unemployment rates, and the government's inability to fix the nation's problems. The immigrants of the second generation faced these problems too. He observed such a so-called policy and racial discrimination as a threat to the whole world. Hanif Kureishi levels this kind of immigrant's policy and racial otherings as against the interest of the whole of Europe. According to Young (2003, p.11), during the $19^{\text {th }}$ century, British empires extended her circle, hence the racial tension comes into existence due to the strict laws of colonization. As Ania Loomba observed (1998 p.6), Westerners think about colonization as a legal process that creates a strong calamity between whites and nonwhites.

\section{Theoretical Background and Literature Review}

According to postcolonial critics, the work of Hanif Kureishi deals with the problems of race, hybridity, sexual minorities, identity, clashes with religion, color binaries, and gender issues. A lot of critics put their valuable comments upon the issue of an identity crisis concerning Kureishi's first novel The Buddha of Suburbia (1989) as under. Thomas Walsh who was a famous critic wrote In his book In Betweeners (2008), that Hanif Kureishi keeps the reader busy to know about English history and Asians past culture and traditions. Walsh (2008) questions the past historical life of a particular protagonist and concludes it as full of cultural complexities and racial tension. Another critic Berthold Schoene (Cosmopolitical novel, 2009) observed that the change in the British culture is due to the multiculturalism in England which can never be mitigated by the passage of time.

Susie Thomas in her monograph on Hanif Kurieshi (2005) feels the anxiety in the social life of a particular protagonist when he migrates from the suburbs to the metropolitan city of London. Moving from a suburban area to the metropolitan city of London, he feels dislocation and homesickness. According to Susie Thomas, Karim's growing uneasiness with the British culture is the indication of Britisher's biased culture and attitude towards him. Louis (2013) in his book Irrepressible adventures with Britannia: personalities, politics, and culture in Britain, commented upon The Buddha of Suburbia (1989) and finds that the uneasiness in Karim's life is the result of a change in British culture and her 1970s racist policy. According to Sara Upstone (2008), Hanif Kureishi's first novel is the embodiment of the differences in cultures and racial tension. She describes the lack of capacity to endure the racism through The Buddha of Suburbia can always be remembered as the racial tension in British and still its consequences upon the readers (Upstone, 2008, p.21). Lill Halen Ellingson (2012) discusses the characteristics of the first and second generation of immigrants in his research entitles Identity and Belonging in Hanif Kureishi's The Buddha of Suburbia (1989).

Likewise, the study contributes certain points that are realized after searching into the gaps in previous researches and adds some new ideas in different dimensions. According to my text knowledge, I could not find a work that covers economic, cultural, racial, and social issues. An extensive review of the existing literature reveals that Kureishi's work has not been subjected to the aforementioned topic because most of the studies dealt with history as well as a political identity. My research here fills in the gap and incorporates most of the issues related to an identity crisis.

\section{Application of Theoretical Framework}

For the analysis of issues of an identity crisis, the postcolonial ideas of Homi K Bhabha are applied to this novel. These ideas are hybridity, mimicry, assimilation, and ambivalence. According to Homi K. Bhabha, hybridity is the mixture of one or more than one culture which came into existence due to colonization and the individual becomes hybrid. Through the repetition of the effects of discriminatory identity, it is a revaluation of the colonial identity. The displacement and deformation of all discrimination and domination can be viewed through hybridity, (The Location of Culture 1994 p. 112). According to Homi Bhabha, mimicry exists as a result of this hybridity, and the colonized try 
to imitate the cultural values of the colonizers/host country but this imitation results in ambivalence for the colonized (The Location of Culture 1994 p.124).

The Buddha of Suburbia (1989) interprets Karim's struggle to imitate the cultural values of the Whites but he remains in an ambivalent state of mind. He is a hybrid character too which creates in him a sense of anxiety throughout the story of the novel as Ranasinha (2002) observed. Despite issues of culture, dislocation, racism, and language, the other issues like political, religious, and economic presence in the novel The Buddha of Suburbia intends to fill the gap for further research which I have discussed in this article

\section{Research Questions}

The current research paper seeks answers to the following research questions.

1. What are the factors behind the identity crisis faced by Karim?

2. What role do Bhabha's postmodern ideas i.e, hybridity, mimicry, and ambivalence play in the social life of the protagonist?

3. How much 1970s British racist policy affected the immigrants?

\section{Research Methodology}

The present article is primarily inductive and thus exploratory due to its textual nature which is based on textual analysis research methodology. Hence, a close reading method is applied to the text of the novel. For this purpose, the researcher read carefully a famous book named Close Reading (The Basics 2018) by David Greenham. The method explains detailed scrutiny of the textual data available for the study which usually consists of five stages, firstly, pre-interpretation stage, second critical analysis stage, third evaluation, fourth verification stage and the last not the least the writing stage in which the researcher wrote his useful comments in the form of an article. The researcher followed all these stages one by one and thus gives a conclusion.

\section{Depiction of Darker Side of the British Culture and Karim's Disappointment With It}

The 1970s British society is full of racial discrimination and has a strong anti-immigrant sentiment. Most of the whites consider Blacks as the lower creature of God. They show vanity and hypocrisy towards them. Even the Blacks were deprived of their basic rights and needs. They were deprived of the necessary education, health facilities, transport, proper government jobs, and basic living standards. They were constricted to their homes. Sometimes, on another occasion, the Blacks try to imitate the cultural values and habits of the whites, in reaction, the Whites make fun of their black skin. For instance, when the Blacks wear the dress of whites' i.e, a pant shirt and try to eat European food, the whites make fun of them. The case was the same as the protagonist of the novel Karim Amir who has become disappointed with the British culture. He is in between two cultures, the one culture of his belongingness to Indian heritage from his father's side Haroon and the other belongs to his mother's side Eva, the British culture. Homi Bhabha explains this situation in his book The Location of Culture 1994 as hybridity. Karim is a hybrid character because he possesses similar as well as opposite qualities at the same time. That's why he often unable to fully embrace his English as well as his Indian identities. In England, Karim's dad Haroon spent the last twenty years of his life with his family to adjust himself to the British culture but he remains directionless. In the long twenty years, he could not embrace his English identity fully. Like his father, Karim faces a similar situation on English soil.

He struggles hard to assimilate himself with the British culture but all in vain. He regularly asks questions about his own identity instead of living here for very long years. Karim thinks that it is his father's monopoly that created an embarrassing condition for them. Karim hates to become an Indian himself. At one moment, when the theatre director Shadwell casts Karim as the role of Mowgli in an audition of Rudyard Kipling's jungle book, the whites make fun of his black skin. Though Karim is thrilled to get the part, he is less thrilled when Shadwell reveals how racist he is? They usually rude nicknames him and refer him to as a "Shotwell" and Shadwell insists him again to wear dark makeup and speak in an Indian accent. Another example of the darker side of the British culture portrayed in the novel is that when dad gives a talk on Eastern philosophy and leads a yoga and meditation workshop, Karim Amir thought that the whites took interest in his father's Indian identity. This shows the hypocrisy and flats out the vanity of the whites towards the black-skinned. However, Karim's father performed this act to his advantage. So Karim's father's Eastern philosophy, yoga, and meditation workshop are for the appeasement of racist attitudes of the white Londoners towards Asians. The prejudice and biased attitudes of the Britishers towards the immigrants' were at the zenith 
during Margaret Thatcher's reign. Karim feels embarrassed totally both in suburbs and in London city due to racial discrimination.

\section{Searching for Karim's Personal and Cultural Identity and the Conflict of his Inner Self}

The protagonist Karim Amir is the victim of his personal and cultural identity and from Karim's perspectives; all the characters and situations of the novel are presented. Hanif Kureishi very well discusses the important social issues of culture, religion, traditions, ethnicity, color binary, and language concerning Karim's cultural and personal identity. Karim Amir could not identify himself with the British culture personally and culturally. As personally Karim Amir is affected by the origin of his Indian heritage, while on the other hand, he is affected culturally due to the prejudice of the English people and their hypocrisy towards him. This biased attitude of the Britishers towards Karim Amir becomes him personally frustrated, alien, and aloof. But on the contrary, Karim Amir should get rid of the frustrating condition by thinking about his English origin and culture even though his father Haroon belongs to Indian heritage. This is the indication of his satisfaction with his inner self which is only a way to shift his social position. He becomes the victim of an identity crisis when he moves from suburbs to London to abandoning all the traditions and culture of suburban life behind in hope of a peaceful life. He always remembers his peaceful days of suburban life and tries to represent these with the present tormenting condition of London city with the support of his origin "perhaps it is the odd mixture of continents and blood, of here and there, of belonging and not, that makes me restless and easily bored" (p.3).

According to Karim Amir, the present London city is full of racial discrimination and multicultural one which creates ambivalence in him. To understand himself, Karim Amir indulged in seeking his personal and cultural identity because he is being agreed with it. He describes this situation by giving references to the problems of his personal and cultural identity in a manner that he was looking for troubles, actions, sexual interests, and movement of any kind because things have become very absurd, slow, and heavy in his family. What is the cultural background of Karim? Karim brought up in Britain, he behaves like the English and speaks English. That's why he identifies himself as an Englishman. He never take interest in adopting his father's religion; he has never been Indian and does not know the Indian language. The only way Karim connects his cultural identity with his Indian roots with his interests in eating traditional Indian dishes, yoga practices, dresses, and spicy foods. That is why Karim thinks about himself as a true Englishman rather than an Indian. He disbelief in showing the heritage of Indian roots because it is against the norms of British society.

However, he can't reject the idea of being an Indian because Karim has interaction with his Indian father, Jamila, and her Indian family too. The society in which Karim Amir lives is the indication of complexities, racism, and color binaries through which he becomes the victim of his personal and cultural identity. He has been called by the Whites as Curryface and Shitface and while he's coming back home, he is covered in snot and spite, chalk, and wood shaving. He thanks God for his happy returning home from school without serious injury. Karim feels alien because of the people's attitude around him. He feels alienation and dislocation from a very young age. He feels himself to be an Englishman but on the other hand, he feels that his root belongs to Indian heritage. He spends most of his time with his uncle and aunt who are Indians and not Englishmen. With their Indian roots both Haroon and Anwar try to connect with Karim and introduced Indian culture and traditions. Despite Karim's desires and ideas, the system of Education is full of the biased attitude of the Whites towards immigrants in England. As mentioned earlier Karim Amir was happy with the days; he could walk home after school without serious injuries. According to him, the black-skinned people are not protected in schools, colleges, and universities of England. Karim Amir thinks that he and his family have been living in England with people of different nations and cultures for many years and the people should be tolerant and accepting of his family but the situation is quite different from the fact that England is full of racial practices. He thinks that how he grows up and accepts his identity when people tell him that he is alien and he does not belong in the group which is called English and he also does not feel better with the Indian group at home. This situation is unacceptable, horrible, and alarming for him. Moreover, the parents of Helen think about him as unequal and unacceptable for their daughter. Later on, this attitude of Helen's parents oppressed Karim Amir very much. From this incident, the author Hanif

Kureishi depicted the harsh reality and social interaction between Englishmen and immigrants. Karim Amir belongs to the lower class that is why he and his father Haroon find it 
difficult to maintain their lives and change their social position both in suburbs and in London city. They move to London with the hope to change their social status. It is significant for Karim to become an actor in London and he hopes that he would be succeeded from lower middle class to upper class. Karim tries to accept the customs and behavior of other people to be closed with them socially and culturally. While interacting with the representatives of the other social classes and cultures, Karim's vision of his relationship with the people around him and his social practices is rather successful and enchanting which keeps him to feel more reliable and comfortable. On the one hand about the social shift, Karim's flexibility in his identity is better for him. On the other hand, about become an English star, Karim suffers from his hybrid identity. So the protagonist Karim Amir in the story The Buddha of Suburbia (1989) always struggles to search for his personal and hybrid identity.

\section{The Development and Changes in other Characters in the Buddha of Suburbia Haroon and Anwar}

Haroon and Anwar belong to the first generation of immigrants. They dreamt to pursue a peaceful life in London which is full of liberty and frivolity. Anwar decides to run a shop for a better living in the tormenting condition of England. He remains true to his cultural identity and heritage to avoid British stereotypes and identity. Being true to Indian heritage, Anwar decides to marry her daughter Jamila by picking an Indian husband for her in England. He goes on a hunger strike when her daughter refuses to marry her preferred suitor. To find a luxurious life and happiness, Haroon and Anwar try their hard to adjust and survive themselves with the changing condition of British life but all in vain. They seem to be frustrated and absurd in England. Haroon earns his livelihood in London suburbs in a liberal way while Anwar is tangled with his Indian roots. According to him, survival in England is only based on hard work and success.

Haroon plays the role of a guru. Among other immigrants, he gains recognition by using his exotic character but he could not mitigate the immigrant stature. He acts as a guru in the suburbs because he wanted to introduce something unique and special to the British society but he failed in his mission to capture the attention of the British and Indian community around him. He preferred to perform his duties as a civil servant but he cannot be promoted because white people are waiting to be promoted. This is the manifestation of the racist and biased attitude of the Britishers towards him. Haroon wants to be recognized and accepted in England but all his hopes cannot be fulfilled. Just like Anwar, Haroon wanted to survive in a British harsh reality with his children. He desires his son Karim to become a doctor or a lawyer but his dreams do not become fulfilled and as a result, he loses all the possibility of gaining success in England. He looked down upon both by Indian as well as English families. So Haroon and Anwar who belongs to the first generation of immigrants become the victim of identity crisis in English society.

\section{Jamila}

Jamila belongs to the second generation of an immigrant. She has her own personal and cultural identity. She does not concentrate on the issue of her cultural otherness. She does not care about her cultural identity and fights for her rights in England. She takes interest in politics, her present social status, and freedom instead of radical views about identity. She thinks of an identity crisis as a global dilemma where everyone is free to live according to his or her own choice. That is why she wanted to marry according to her desire rather than her parents' pressure. The second-generation immigrants inclined themes with the British culture but this sort of inclination never fetched the desired effects for them. Jamila is more liberal and active in accepting the traditional norms of England. Karim observes about Jamila that "she was forceful and enthusiastic, Jamila, She seemed to be leaning forward, arguing, persuading" (51). She refuses to live according to the cleaning habits of her parents. Her ideas are quite different from her father's vision of women's status in society and a family. Her marriage with Changez is an indication of her reaction against the conservative ideas in England. To live in a commune is another example of her feministic and liberal ideas which shows her identity. Jamila's ideas about cultural identity are different from his father's ideas. Being the second generation of immigrants, Jamila is affected by the traditions and culture of England society in which she was born. She is the embodiment of liberal ideas and attitudes while on the contrary, her father Anwar's ideas remain fixed to his Indian roots and culture. So Jamila's ideas and liberal attitudes towards modern life can be discussed as a multicultural one. 


\section{Identity Crisis from the Non-Immigrant Perspective \\ Eva and Margaret}

Eva and Margaret were born in England. They form their British cultural identity because they are familiar with it. Eva Kay who finds Haroon very exotic is the "other woman'. She knows all the aspects of English culture and traditions. For gaining higher status in English society, Eva tries to overcome the boundaries of life in the Suburbs. She is not satisfied with the present situation in suburbs. Her identity forced her to move forward and then to modify the condition of her present life. Her plans to move to London from a suburb is an indication of a definite problem with her identity. Due to cultural differences, Eva Kay tries to use Haroon's ethnicity as an effective tool for attracting the mass's attention. The Indian culture is never a part of her cultural identity but it is an important aspect of her identity. On the other hand, Margaret focused on members of her family's interests. She is the depiction of unhappy marriage with Haroon. She is not satisfied with the Indian culture and traditions through which she attached. She depicts an identity crisis on her part due to her attachment with the Indian culture in suburbs. Because of the impact of two different cultures, Margaret and Eva's identities are a culturally mixed one. Although, they show their hybrid identities, yet their interest in the Indian culture and tradition is an indication of their ignorance of the British culture.

\section{Charlie}

Eva's son Charley passionately struggles to find his place in the world in which he can achieve his goals and become famous. He experienced the fact of being an immigrant in the USA. The life of an immigrant is linked with a kind of struggle for a better position within the foreign society. Within a foreign society, it is impossible to avoid definite assimilation because every person makes his or her own choice in respect to follow the foreign culture. Charlie always tries to show his personal and cultural identity because he is a nonimmigrant in England. He imitates the habits of Asian immigrants and he wants to become a successful man in the future which is necessary for his successful journey to the USA. The lack of his father's attention towards him caused him to become the victim of an inferiority complex. So Charlie sold his cultural identity. He tries himself with the traditions of his culture and adjusts to it. His personal and cultural identity is the indication of his dissatisfaction with the culture in which he lives while on the other hand, Karim Amir and Jamila's identities are an indication of their racial and biased environment. His ability to assimilate with the present situation is more complex and ambiguous as compared to Karim and Jamila in their position in British society and struggle for their identity. So Charlie becomes the victim of an identity crisis in the USA and he tries to overcome it.

And so I sat in the center of this old city that I

Loved, which itself sat at the bottom of a tiny

Island. I was surrounded by people I loved, and I felt happy and miserable at the same time.

I thought of what a mess every has been,

but that it wouldn't always be this way.

Discussion and Analysis

(Kurieshi, 1989, p. 112)

Karim introduces himself as an Englishman born and bred almost from the South London Suburbs.

"I am an Englishman born and bred almost"

(The Buddha of Suburbia ch.01 p.03)

Here, almost is the indication of his hybrid character. Why almost represents his hybrid character because he belongs to Indian heritage from his father's side and English heritage from his mother's side. Notwithstanding, the above-mentioned quote interprets Bhabha's idea of hybridity.

Karim watches the Indian gravediggers at Anwar's funeral and begins to come to terms with his Indian identity sayings,

"I did feel looking at these strange creatures now-the Indians-that ... these were my people," (The Buddha of Suburbia ch.14 p.12)

Here, at Anwar's grave, he faces the potential for an individually authentic version-his hybrid version. His work in theatre has exposed him to a white fetish version of his father's race because his father is an Indian having black skin. Thus, above mentioned quote explains Bhabha's idea of hybridity. 
In an audition, theatre director Shadwell invites Karim to cast and play the role of Mowgli a character which is taken from Rudyard Kipling a jungle book to make fun of his black skin.

"I mimic and assimilate myself with what the whites believes and ridicule"

(The Buddha of Suburbia ch.17 p.77)

Why Karim imitates the cultural values of the whites because he wants to assimilate himself with the British culture. This highlights Bhabha's postmodern idea of mimicry.

Karim feels directionless and uncertain in England, which shows his quest for identity.

"And so I sat in the center of this old city that I loved, which sat at the bottom of a tiny island. I was surrounded by people I loved, and I felt happy and miserable at the same time. I thought of what a mess everything had been, but that it wouldn't always be his way."

(The Buddha of Suburbia p.234)

The novel discusses Karim's struggle to find his place in the world and discovers who is he? His Indian and English identities are an indication of his ignorance, dislocation, and certainty which creates a sense of ambivalence for him as Bhabha explains it in his idea of ambivalence.

"You see, I have come to believe in self-help, individual initiative, the love of what you do, and the full development of all individuals. I am constantly disappointed by how little we expect of ourselves and the world"

(The Buddha of Suburbia ch.07 p.86)

Karim amir experienced the dilemma of identity in England in the same way as Hanif Kureishi experienced it with his own eyes when he says,
"And so I sat in the center of this old city that I
Loved, which itself sat at the bottom of a tiny
Island. I was surrounded by people I loved,
and I felt happy and miserable at the same time.
I thought of what a mess every has been,
but that it wouldn't always be this way".
(Kurieshi, 1989, p. 112)

Karim discusses the racist attacks during the 1970s political and social discontent in England when he returns home. A neo-Nazi political party (The National Front) shows a strong anti-immigrant sentiment towards Karim and his family.

"Every day I considered myself lucky to get home without serious injury"

(The Buddha of Suburbia Part 1p.11)

In the 1970s decade, there was severe political and social discontent in England. With the 1979 election, the liberalism characterized the 1960s experienced a sharp spring towards conservatism during this period. When the British government failed to serve the immigrants, a political movement appeared in response to this failure. Karim Amir took a great involvement and interest in this political movement. The alarming racist attitudes are also observed by him. At that time, the unemployment rates, downfall of the economy, lack of educational and health facilities were very common and the British government could not control it. From 1978 to 1979, the difficulties reached a peak when a large number of union workers went on strike and protested on their pay against the so-called Winter of Discontent. Bart Moore Gilbert (2001, p.127) indicates that by the passage of time, the middleclass immigrants tried to maintain their lives with difficulties. Karim felt that the atmosphere of Great Britain is based on conservatism which results later in racism. He thinks that the concept of racism came into existence when Great Britain divided its colony of the subcontinent into independent states i.e, Pakistan, and India approximately 25 years ago. Even, the political party The National front shows a strong anti-immigrant sentiment which causes injustices and casualties in England. Hanif Kureishi very well depicted the social and political discontent of 1970s England in which he lived.

The independence of British India resulted in causalities and animosity in religions, politics, social and economic matters (Bill Archcroft, Griffiths \& Tiffin 2007). A large number of Pakistani and Indian individuals sacrificed their lives for the sake of their freedom. Many of them migrated to other European countries especially France, Italy, Germany, and England. Young people like dad and Anwar experienced the chanting of anti-Muslim slogans and behavior of their Hindu neighbors outside their homes. At present, Karim Amir watches this animosity in an intensified manner. There was a great threat to Karim's family and friends due to the National Front which was a neo-Nazi political party that showed an extreme anti-immigrant sentiment. Through Anwar's shop window, the 
neo-Nazi political party the National Front is responsible for throwing a pig's head and attacked Changez and injured him seriously because the Nazi party considered him to be a Pakistani. This violent act does not stop him from being racist; he is vocal throughout the novel about his hatred of Pakistani people. This violent act is an indication of the racist attitudes of the White Englishmen towards the Pakistani people. In turn, the racism in England may not be mitigated and the British government is not in a situation to eradicate this evil from its soil forever.

\section{Conclusion}

In short, the study depicts in-depth meanings behind the identity crisis faced by Karim. In response to question no.2, there were ethnic, cultural, religious, economic, and social factors that are the main causes of identity crisis because of the disturbing and confusing situation of England during the 20th century. By responding to Homi K. Bhabha's postmodern ideas of hybridity, mimicry, assimilation, and ambivalence, the first and second generation of immigrants like Karim, Jamila, Charlie, Harron, and Anwar imitate the cultural values of the whites. Hanif Kureishi very well depicted the 1970s society of England in his novel The Buddha of Suburbia (1989) which is very alarming and considerable for the whole world. The writer sets straight the whole scenario of the 1970s century of London which is full of racial discrimination and biased. The protagonist Karim Amir and other characters of the story describe their crisis of identity from a social, political, religious, and economic point of view. The first generation of immigrants like Anwar and Haroon depict their social and cultural identity and they are fixed with their Indian roots and traditions and do not compromise with it, while on the contrary, the second generation of immigrants like Karim and Jamila the daughter of Anwar try their best to adopt the English cultures and traditions to enjoy rock and rolls, luxuries of England society but they both seem frustrated in British culture because of the biased attitudes of the Whites. For adjusting themselves to the British culture they try to imitate the cultural values of the Whites but this mimicry never fetched the desired effect for them and the result is simply ambivalent for them. The Whites consider themselves as superior and supreme to immigrants especially the Asian people and they are not interested in accepting Asians. That is why the Asian are deprived of their personal, cultural, social, and political identities. However, this idea is based on illusion because it indicates the false metaphysics of philosophical traditions of Western societies which have described discriminations as the refusal of hybrid and cultural identity and affixed this refusal to the minor group which is called Asian peoples. The novel shows that this illusion is based on drama because both White British and the Asians continuously change their cultural and ethnic identities and introduce themselves again on British soil. The subversive influence of hybridity and the presentation of the power of performativity by the Asians reveal a dangerous threat to their lives in foreign countries. The author, Hanif Krieshi himself is the victim of the identity crisis in England and he saw the whole dilemma of identity crisis through his own eyes. Within the range of postcolonial criticism, this dilemma has led the novel to become hotly debated.

\section{References}

Ashcroft, B., Griffiths, G., Tiffin, H. Ed., (2007). Post-Colonial Studies; the Key Concepts, New York: Routledge.

Bhabha, H. K. (1997). Interrogating Identity: The Location of Culture, London: Routledge, Print.

Bhabha, H. K. (1997). Of Mimicry and Men: The Location of Culture, London: Routledge, Print.

Bhabha, H. K. (1997). Signs Taken for Wonders: The Location of Culture, London: Routledge, Print.

Ellingsen, L. H. (2012). An Englishman born and bred, almost Identity and Belonging in Hanif Kureishi 's The Buddha of Suburbia. (Masters Thesis, The University of Oslo, Norway). Retrieved from: https://www.duo.uio.no/bitstream/handle/10852/34757/AnxEnglishmanMA1.pdf?sequence=1\&isAllowed=y (Retrieved on June 10, 2020).

Felski, R. (2000). Nothing to Declare: Identity, Shame, and the Lower Middle Class. Publications of the Modern Language Association of America.

Grin, M. S. (2005). The Search for Identity in "The Buddha of Suburbia" by Hanif Kureishi. https://www.grin.com/document/388006. (Retrieved on June 28, 2020).

Greenham, D. (2018). Close Reading The Basics, Routledge Print.

Gilbert, B. M. (2001). Hanif Kureishi, Manchester: Manchester University Press, Print.

Gergen, J. K. (1991). The Saturated Self: Dilemmas of Identity in Contemporary Life. Basic Books, New York.

Jameson, F. (1991). Postmodernism or the Cultural Logic of Late Capitalism, Duke University Press, 


\section{Washington.}

Kara, G. (2020). The Problem of Immigrant Identity In Buddha of Suburbia By Hanif Kureishi. Akademik Dil Ve Edebiyat Dergisi, 4(1), 179-199. https://doi.org/10.34083/akaded.703403

Kaleta, C. K. (1998). Hanif Kureishi: Postcolonial storyteller, The University of Texas Press, Austen. Kureishi, H. (1989). The Buddha of Suburbia. Faber and Faber Limited, London Press.

Kurieshi, H. (1995). The Black Album, Faber and Faber Limited, London Press.

Kurieshi, H. (2005). Something to Tell You, Faber and Faber Limited, London Press.

Kalpakl1, Fatma. (2015). Searching For Identity In Hanif Kureishi's The Buddha Of Suburbia Hanif Kureishi'nin Varoşların Budası Adlı Romanında Kimlik Arayışı. 33. 81-86. Retrieved from: https://www.researchgate.net/publication/317168482_Searching_For_Identity_In_Hanif_Kur eishi's_The_Buddha_Of_Suburbia_Hanif_Kureishi'nin_Varoslarin_Budasi_Adli_Romaninda _Kimlik_Arayisi/citation/download (Retrieved on June 25, 2020).

Loomba, A. (1998). Colonialism/ Postcolonialism, London: Routledge, Print.

Louis, W. R. (2013). Irrepressible adventures with Britannia: personalities, politics, and culture in Britain. I.B. Tauris.

Onmus, S. (2012). Hybrid Identities in the Buddha of Suburbia by Hanif Kureishi and The Namesake by Jhumpa Lahiri. (Masters Thesis, The Graduate School of Social Sciences of Middle East Technical University, Middle East). Retrieved from: http://citeseerx.ist.psu.edu/viewdoc/ download?doi=10.1.1.634.2309\&rep=rep1\&type=pdf (Retrieved on June 20, 2020).

Ranasinha. (2002). Hanif Kureishi: Writing the self. Manchester University Press.

Rushdie, S. (1992). Imaginary Homelands: Essays and Criticism 1981-1991, London: Granta Books, Print.

Schoene, B. (2009). The Cosmopolitan Novel. Edinburgh University Press.

Said, E. (1997). Covering Islam: How the Media and the Experts Determine How We See the Rest of the World. First Vintage, New York.

Said, E. (1979). Orientalism. First Vintage, New York.

Thomas, S. (2005). A Monograph on Hanif Kureishi. Palgrave Macmillan, Basingstoke Press.

Upstone, S. (2008). A question of black or white: Returning to Hanif Kureishi's The Black Album, The Open Humanities journal, 4 (1), 1705-9100.

Walsh, T. (2008). The in-betweeners: Irish animation as postcolonial discourse. Loughborough University.

Young, R. (2005). Colonial Desire, Hybridity in Theory, Culture and Race, London: Routledge, Print.

Yousaf, N. (2002, p. 8-26). Hanif Kureishi's The Buddha of Suburbia: Readers Guide. The Continuum International Publishing Group Inc., New York. 